\title{
How to Improve Soil Anti-adhesion by Studying the Micro Relief of the Cuticle Surface of Digging Beetles: Exploring the Biodiversity of Argentina as a Source of Bioinspiration
}

Lorena Setten $^{1}$, M. Victoria Sánchez ${ }^{2}$, Jorge F. Genise ${ }^{2}$ and Eduardo A. Favret ${ }^{3}$

${ }^{1}$ Instituto Nacional de Tecnología Agropecuaria - INTA, Hurlingham, Buenos Aires, Argentina, ${ }^{2}$ CONICET - Museo Argentino de Ciencias Naturales "Bernardino Rivadavia", Ciudad Autonoma de Buenos Aires, Ciudad Autonoma de Buenos Aires, Argentina, ${ }^{3}$ Instituto Nacional de Tecnología Agropecuaria (INTA) - CONICET, Hurlingham, Buenos Aires, Argentina

Some years ago, Tesouro et al. (2018) proposed a possible solution for decreasing adhesion of the soil particles to the surface components of agricultural machinery based on a biological system (biomimetic studies). This has the purpose of reducing the drawing force on the tool with a consequent reduction in fuel consumption. They analyzed the micro topography (micro relief) of the cuticular surface of the Diloboderus abderus (Coleoptera, Scarabaeidae) using a scanning electron microscope (SEM). The main features found on the beetle's head and pronotum were the presence of dimples, showing a short hair in their center, and distributed randomly. Based on the dimples of the thorax Tesouro et al. designed a macro topography pattern for the upper surface of a steel shovel for tilling (agricultural tool). The results indicated a reduction of the average traction demand of approximately $7 \%$ for the biomimetic shovel [1]. Presently, we are exploring the micro relief of the cuticle surface of other beetle species living in Argentina that are considered as true soil diggers to find new anti-adhesion patterns. Beetles were collected from different localities and provinces showing different types of soils and climatic conditions. Thorax images were obtained using a SEM Philips-XL Serie 30. The following beetle species were analyzed: Anomiopsoides fedemariai (Mendoza), Canthon mutabilis (Chaco), Eucranium arachnoides (Mendoza), Frickius variolosus (Chubut), Malagoniella argentina (La Rioja), Ontherus sulcator (Buenos Aires), Pseudocanthon sp. (Chaco), Sulcophanaeus imperator (Mendoza), S. menelas (Buenos Aires) and Taurocerastes patagonicus (collected in southern Chile but also present in Argentinian Patagonia). The first result was that the cuticle surface of all of them presents dimples, which showed different dimensions and distribution among species. Figure 1 shows four different dimple morphologies. Dimples were not perfect circles, so two perpendicular dimensions were considered (d1 and d2) (figure 2). Table I shows the mean dimensions (Mean d1, Mean d2) and mean distances (Mean D) of the measured dimples, as well as the circle eccentricity (Mean $\mathrm{d} 1 /$ Mean $\mathrm{d} 2$ ) and the ratio $\mathrm{d} /$ Mean $\mathrm{D}$, being $d=($ Mean $\mathrm{d} 1+$ Mean $\mathrm{d} 2) / 2$. More than fifteen dimples were measured for each species. The results indicate that there is not a unique dimple dimension. The dimple eccentricity and the distance among them vary in a certain range. In spite of the differences of dimensions, morphology and distribution found among these species, the presence of dimples is a conserved characteristic that supports the idea that they may be one of the main causes for anti-adhesion properties [2]. These results are preliminary. With more analysis, and adding species, we expect to found a more specific relationship among morphologies and distribution of dimples, and beetle species and/or the type of soil that allows as to improve the design of macro topography patterns in surfaces of agricultural tools [3].

Table I: Dimples measurements: mean dimensions (d1, d2), mean distances (D) of the dimples and the relationships circle eccentricity (Mean d1/Mean d2) and ratio $d /$ Mean $\mathrm{D}$, being $d=$ Mean $\mathrm{d} 1 /$ Mean $\mathrm{d} 2 / 2$. 


\begin{tabular}{|c|c|c|c|c|c|}
\hline Species & $\begin{array}{l}\text { Mean d } \\
{[\mu \mathrm{m}]}\end{array}$ & $\begin{array}{c}\mathrm{d} 1 \text { Mean } \\
{[\mu \mathrm{m}]}\end{array}$ & $\begin{array}{l}\text { d2 Mean d1 } \\
\text { d2 }\end{array}$ & $\begin{array}{r}\text { 1/ Mean Mean } \\
{[\mu \mathrm{m}]}\end{array}$ & $\begin{array}{l}\mathrm{D}[(\text { Mean } \mathrm{d} 1+\text { Mean } \\
\mathrm{d} 2) / 2] / \text { Mean } \mathrm{D}\end{array}$ \\
\hline $\begin{array}{l}\text { Anomiopsoides } \\
\text { fedemariai }\end{array}$ & $35.1 \pm 8.1$ & $36.1 \pm 7.5$ & .5 & $\begin{array}{l}570.0 \\
80.4\end{array}$ & ${ }^{ \pm} 0.06$ \\
\hline Canthon mutabilis & $19.9 \pm 3.4$ & $25.8 \pm 3.3$ & 30,8 & $\begin{array}{l}150.1 \\
28.3\end{array}$ & ${ }^{ \pm} 0.15$ \\
\hline $\begin{array}{l}\text { Eucranium } \\
\text { arachnoides }\end{array}$ & $51.0 \pm 9.6$ & $\begin{array}{l}57.0 \\
10.4\end{array}$ & $\pm_{0.9}$ & $\begin{array}{l}987.0 \\
171.4\end{array}$ & $\pm_{0.05}$ \\
\hline Frickius variolosus & $\begin{array}{l}139.9 \\
23.5\end{array}$ & $\begin{array}{l} \pm 154.0 \\
16.5\end{array}$ & ${ }^{ \pm} 0.9$ & $\begin{array}{l}363.3 \\
69.3\end{array}$ & ${ }^{ \pm} 0.40$ \\
\hline $\begin{array}{l}\text { Malagoniella } \\
\text { argentina }\end{array}$ & $10.1 \pm 2.0$ & $27.4 \pm 3.9$ & 90.4 & $\begin{array}{l}195.3 \\
35.5\end{array}$ & ${ }^{ \pm} 0.09$ \\
\hline Ontherus sulcator & $21.8 \pm 3.3$ & $37.6 \pm 5.1$ & 10.6 & $\begin{array}{l}347.8 \\
71.9\end{array}$ & ${ }^{ \pm} 0.08$ \\
\hline Pseudocanthon sp. & $11.8 \pm 1.25$ & $526.8 \pm 4.0$ & $\begin{array}{ll}0 & 0.4\end{array}$ & $\begin{array}{l}141.8 \\
24.5\end{array}$ & ${ }^{ \pm} 0.13$ \\
\hline $\begin{array}{l}\text { Sulcophanaeus } \\
\text { imperator }\end{array}$ & $48.8 \pm 6.2$ & $89 \pm 13.4$ & $\begin{array}{ll}4 & 0.5\end{array}$ & $\begin{array}{l}282.8 \\
47.2\end{array}$ & ${ }^{ \pm} 0.24$ \\
\hline $\begin{array}{l}\text { Sulcophanaeus } \\
\text { menelas }\end{array}$ & $37.4 \pm 4.4$ & $\begin{array}{l}77.6 \\
16.0\end{array}$ & $\pm_{0.5}$ & $\begin{array}{l}287.1 \\
49.9\end{array}$ & ${ }^{ \pm} 0.20$ \\
\hline $\begin{array}{l}\text { Taurocerastes } \\
\text { patagonicus }\end{array}$ & $74.5 \pm 13.6$ & $\begin{array}{l}6 \quad 81.3 \\
20.2\end{array}$ & \pm 0.9 & $\begin{array}{l}694.3 \\
116.7\end{array}$ & $\pm 0,11$ \\
\hline
\end{tabular}





Figure 1. SEM images of beetle's pronotum: 1- Canthon mutabilis, 2- Frickius variolosus, 3Malagoniella argentina, 4- Sulcophanaeus menelas.

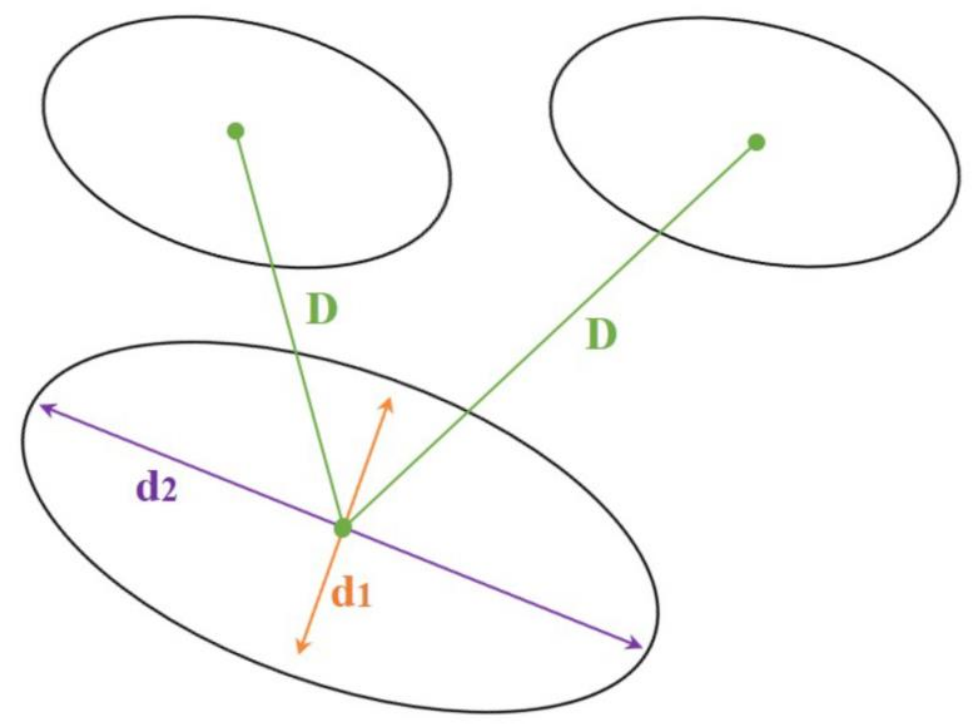


Figure 2. Diagram of the dimple dimensions (d1, d2) and the distance (D) between dimples.

\section{References}

[1] Tesouro et al. Microsc. \& Microanal., 24(1) (2018), p. 1190-1191.

[2] Satomi T et al. $15^{\text {th }}$ Int. Conf. on Experimental Mechanics (ICEM15). 2634 (2012), p. 1-9.

[3] Authors acknowledge to Lic. Fabián Tricárico of the Scanning Electronic Microscopy Laboratory (Museo Argentino de Ciencias Naturales "Bernardino Rivadavia" - CONICET) for the micrographs and to the collectors of Instituto Argentino de Investigación de las Zonas Áridas (IADYZA) for the beetle's samples. 